\title{
THE APPLICATION OF SIMULATION TO PRODUCT SERVICE SYSTEMS:
}

\section{A REVIEW (WIP)}

\author{
Emmanuel O. Musa, Andrew Greasley and Pavel Albores \\ Aston Business School, \\ Aston University, \\ Birmingham, UK \\ musaeo@aston.ac.uk, a.greasley@aston.ac.uk,p.albores@aston.ac.uk
}

\begin{abstract}
One innovative strategy among product manufacturers is to compete through the delivery of services to their clients. The range of advanced services provided by these manufacturers are underpinned by a system known as product-service systems (PSS). Based on a literature review, a description of a PSS with its dynamic behaviour is provided. Three PSS modelling and simulation methods (system dynamics, discrete event simulation and agent based simulation) and the nature of their application in the context of PSS are identified and discussed. Results indicate DES as the mostly used simulation approach accounting for over $50 \%$ papers reviewed due to its ability to model the dynamic behaviour of PSS over time. Previous and current research have focused on the design and in-service phase of PSS lifecycle phase. The choice of specific simulation method is dependent on the objectives intended, which include optimization of design configuration during the design and development phase and performance evaluation and optimization of resource utilization during the in-service phase of a PSS lifecycle. An area for further research is the application of simulation as a tool for cost analysis and cost estimation.
\end{abstract}

Keywords: simulation, product-service systems, review

\section{INTRODUCTION}

The decline in the manufacturing sector in developed economies have led to the rise in service-based economies, characterized by the emergence of new business models, which combine product and services as part of an integrated offering known as product-service system (PSS) (Tukker \& Tischner, 2006). According to Goedkoop, et al (1999), a PSS is a marketable set of products and services capable of jointly fulfilling a user's needs. A PSS extends the functionality of a product by incorporating additional services (Mont 2002; Oliva \& Kallenberg 2003; Neely 2008) with the purpose of offering value in use (Baines et al., 2011). This paradigm shift provides Original Equipment Manufacturers (OEM) with the opportunity to access and grow new revenue streams, decrease the volatility of cash flows throughout the life of a product, facilitate the sale of goods, foster closer and longer relationships with their clients and attain competitive advantage while delivering value to customers (Gebauer et al. 2008).

Product-service systems exhibit dynamic behaviour since they underlie the delivery of services. Services, due to characteristics such as inseparability and variability, consist of many stochastic elements, which are largely driven by human behaviour and demands (Phumbua \& Tjahjono, 2010, 2012). Furthermore, the need for an effective collaboration and interaction between the OEM, clients and a network of stakeholders and actors along the value chain for the delivery of agreed outcomes highlights some of the complexity of 
transitioning to service based models. This presents a challenge to managers in specifying consistent and efficient industrial configurations for their business processes (Chalal et al, 2015).

Furthermore, most PSS exist in the form of long-term contracts spanning the lifecycle of the asset/product (Baines et al., 2011). The manufacturer (who is now the service provider) assumes responsibility for the costs and risks associated with the long-term performance of the product (Oliva \& Kallenberg, 2003). PSS contracts are characterised by uncertainties which are caused by the stochastic nature of the service life of the hardware component of a PSS, hardware usage, utilization and operations over the duration of the contract (Datta and Roy, 2010). Unexpected increases in demand and loss of capacity are other factors that increase the level of uncertainty in PSS contracts (Lagemann and Meier, 2014). As a consequenc, firms which offer advanced services delivered via a PSS experience a lack of decision support in determining robust capacity planning strategies in highly dynamic and uncertain environments (Lagemann and Meier, 2014). With a long-term payback period and uncertainty of future demand (Erkoyuncu et al, 2009) the impact on several enterprise performance parameters, performance drivers and factors influencing the economic costs of delivering agreed outcome via a PSS can be significant. For a complex system like a PSS simulation can be employed as a tool to provide insight into its dynamic behaviour. Simulation has been widely used in manufacturing and service operations across a range of industries and sectors to conduct a priori assessment, evaluate performance, optimize design configuration and assess economic performance of product and services processes. This paper reviews the literature on the application of simulation to the analysis of product-service systems. It identifies in the literature study where a specific simulation technique is used, the context of use, the purpose of use and the result achieved. Further work will then be proposed.

\section{LITERATURE REVIEW}

The literature review covers the application of three simulation techniques (discrete event simulation, system dynamics and agent based simulation) in any area of product-service systems. The review also highlights the aim and objectives that were realised from using these techniques. The main databases that were used to identify papers include Scopus, Web of Science, Science Direct, ProQuest, Google Scholar and papers from proceedings of the annual CIRP conference on Industrial Product Service Systems. The date of publication was set between 2000 and 2016. The earlier date was chosen as most product-service systems at the start of the millennium were product-oriented services such as after-sales service contracts and support contracts where manufacturers provide services that supported the use of products. The following key words and research strings were used in the search: availability-based contracts and simulation, product-service systems and simulation, servitization and simulation, uncertainty modelling and simulation in services, product-service system design and simulation. To select the most relevant papers, a rejection criteria was set. Exclusion criteria include papers that focused on PSS but not simulation and papers that cited simulation techniques but whose aim was not to evaluate the application of simulation techniques. Papers that discussed simulation techniques within the context of manufacturing but not PSS were also excluded. Other papers excluded includes research papers where optimization techniques (nonsimulation) and static/deterministic analytical techniques (differential algebra and Monte Carlo simulation) were used to analyse product-service system. However, papers where any of the three simulation approaches were used alongside other non-simulation techniques were included.

\section{RESULTS AND DISCUSSION}

A total of 99,371 articles were found at first. Upon the application of the rejection criteria, the number of articles was reduced to 236 (table 1). The review found that simulation techniques are used in several areas of PSS research including performance evaluation, optimization, sensitivity analysis, forecasting and cost estimation, evaluation of sustainability, uncertainty modelling across design and development and the inservice and assets disposal phases of the PSS lifecycle. In the design and development of PSS simulation is used to evaluate design configurations (Phumbua, 2012). In the in-service phase, simulation is used to estimate the costs of delivering the agreed outcomes via a network of service support actors within a system 
(Kyösti, et al, 2014; Löfstrand et al,2014). A significant proportion of the total article count consists of the application of DES (184), followed by systems dynamics (27) and agent based simulation (25). This is unsurprising since DES can deal with the complexity of PSS. DES can be used to address the variability, uncertainty and risk over the in-service phase of a PSS contract (Kyösti \& Reed, 2015; Weidmann et al, 2015). However, the use of agent based simulation is growing in PSS research since it provides a window to assess how interaction of individual agents gives rise to emergent system behaviour (Wrasse et al 2015). Over $50 \%$ of the papers reviewed focused on the design and development phase of the PSS and a further $30 \%$ on the in-service phase while less than 20 papers focused on simulation as a tool for cost analysis and cost estimation. Datta and Roy (2010) argue that the use of simulation techniques employed in PSS research are data intensive and very much rely on historical data availability, which in part constitute a challenge when the PSS design is novel.

Table 1: Summary of Simulation Type by PSS Type

\begin{tabular}{|c|c|c|c|c|}
\hline Simulation type & $\begin{array}{l}\text { Number } \\
\text { of papers }\end{array}$ & $\begin{array}{l}\text { PSS life cycle } \\
\text { Phase }\end{array}$ & PSS Types & Examples \\
\hline System Dynamics & 27 & $\begin{array}{l}\text { Design } \\
\text { In -service }\end{array}$ & $\begin{array}{l}\text { Result-oriented } \\
\text { services }\end{array}$ & $\begin{array}{l}\text { Wrasse et al } 2015 \\
\text { Phumbua and Tjahjono, } \\
2012 \\
\text { Lee et al, } 2015 \\
\text { Bianchi et al, } 2009\end{array}$ \\
\hline $\begin{array}{l}\text { Discrete Event } \\
\text { Simulation }\end{array}$ & 184 & $\begin{array}{l}\text { Design, } \\
\text { Development } \\
\text { In-service, } \\
\text { Disposal }\end{array}$ & $\begin{array}{l}\text { Product-oriented } \\
\text { services } \\
\text { Use-oriented services } \\
\text { Result-oriented } \\
\text { services }\end{array}$ & $\begin{array}{l}\text { Bowman and Schmee, } \\
2011 \\
\text { Loftsrand et al } 2014 \\
\text { Reed et al, } 2013 \\
\text { Kyosti and Reed, } 2015 \\
\text { Kimita et al } 2012\end{array}$ \\
\hline $\begin{array}{l}\text { Agent Based } \\
\text { Simulation }\end{array}$ & 25 & $\begin{array}{l}\text { PSS development } \\
\text { In service }\end{array}$ & $\begin{array}{l}\text { Result-oriented } \\
\text { Use -oriented }\end{array}$ & $\begin{array}{l}\text { Wrasse et al } 2015 \\
\text { Maisenbacher et al } 2014 \\
\text { Lovric et al } 2013 \\
\text { Kim and Yoon, } 2014\end{array}$ \\
\hline
\end{tabular}

\section{CONCLUSION AND FURTHER WORK}

The results obtained in this literature review indicate the range of areas the three simulation techniques have been used in modelling PSS. All three simulation types have been used across the lifecycle phases of a PSS ranging from design and development phases to in-service and disposal phases to evaluate design 
configurations, optimize resources utilization and predict the cost of support system services required to support the use of the asset or delivery of the performance outcomes. Articles covering the PSS design phase account for over $50 \%$ of the papers reviewed which aligns with the common practice of service providers and PSS designers to assess the viability of a PSS at this stage. However, fewer than 20 papers focused on the use of simulation as a tool for cost estimation and cost analysis. This raises an area for further study and there is ongoing research into assessing discrete event simulation as a tool for cost estimation and cost analysis of PSS contracts. DES has been identified as the most used simulation technique due to its ability to model dynamic behaviour and uncertainties at the operational level of a PSS provider over time. Since service is described as deeds and processes (Zeithaml and Bitner, 2000) delivering a service via a PSS requires activities, which require the utilization of resources over time, to be performed by the service provider (Datta and Roy, 2010). This makes DES a commonly used simulation tool for PSS evaluation across all life phases due to the ability of DES to model different scenarios, provide insight on how state variables within the PSS change with variation in activities and input parameters as well as evaluate performance over time.

\section{REFERENCES}

Baines, T., Lightfoot, H., \& Smart, P. 2011. "Servitization within manufacturing: Exploring the provision of advanced services and their impact on vertical integration”. Journal of Manufacturing Technology Management, 22(7), pp. 947-954.

Bianchi, N. P., Evans, S., Revetria, R., \& Tonelli, F. 2009. "Influencing factors of successful transitions towards product-service systems: A simulation approach”. International Journal of Mathematics and Computers in Simulation, 3(1), pp. 30-43.

Bowman, R.A. and Schmee, J., 2001. "Pricing and managing a maintenance contract for a fleet of aircraft engines”. Simulation, 76(2), pp.69-77.

Chalal, M., Boucher, X., \& Marques, G. 2015. "Decision support system for servitization of industrial SMEs: a modelling and simulation approach”. Journal of Decision Systems, 24(4), pp. 355-382.

Datta, P.P. and Roy, R., 2010. "Cost modelling techniques for availability type service support contracts: a literature review and empirical study”. CIRP Journal of Manufacturing Science and Technology, 3(2), pp.142-157.

Erkoyuncu, J. A., Roy, R., Shehab, E., \& Wardle, P. 2009. "Uncertainty challenges in service cost estimation for product- service systems in the aerospace and defence industries". Proceedings of the 1st CIRP Industrial Product-Service Systems (IPS2) Conference, pp. 200.

Gebauer, H., Krempl, R., \& Fleisch, E. 2008. "Service development in traditional product manufacturing companies”. European Journal of Innovation Management, 11(2), pp. 219-240.

Goedkoop, M.J.,van, H.R.M. te Riele,. Rommers, P.J.M. 1999. "Product Service-Systems ecological and economic basics", Report for Dutch Ministries of Environment (VROM) and Economic Affairs (EZ).

Kim, S., Yoon, B. 2014. "A systematic approach for new service concept generation: application of agent-based simulation”. Expert Systems with Applications, 41, pp. 2793-280.

Kimita, K., Tateyama, T. and Shimomura, Y., 2012. "Process Simulation Method for Product-Service Systems Design”. Procedia CIRP, 3, pp.489-494.

Kyösti, P., \& Reed, S. 2015. "Prediction of service support costs for functional products”. Simulation Modelling Practice and Theory, 59, pp. 52-70.

Kyösti, P., Reed, S., \& Sjödin, S. 2014. “A Decision Support Tool for Optimising Support Site Configuration of Functional Products”. Procedia CIRP, 22(1), pp. 175-180. 
Lagemann, H. and Meier, H., 2014. "Robust capacity planning for the delivery of industrial product-service systems”. Procedia CIRP, 19, pp.99-104.

Lee, S., Han, W. and Park, Y., 2015. "Measuring the functional dynamics of product-service system: A system dynamics approach”. Computers \& Industrial Engineering, 80, pp.159-170.

Löfstrand, M., Kyösti, P., Reed, S., \& Backe, B. 2014. "Evaluating availability of functional products through simulation”. Simulation Modelling Practice and Theory, 47, pp. 196-209.

Lovrić, M., Li, T., and Vervest, P. 2013. "Sustainable Revenue management: A smart carden abled agent-based modelling approach”. Decision Support Systems, 54, pp. 1587-1601

Maisenbacher, S., Weidmann, D., Kasperek, D., Omer, M. 2014. “Applicability of Agent-Based Modeling for supporting Product-Service System development”. Procedia CIRP, 16, pp.356-36

Mont, O. K. 2002. “Clarifying the concept of product-service system”. Journal of Cleaner Production, 10(3), pp. 237-245.

Neely, A. 2008. "Exploring the financial consequences of the servitization of manufacturing”. Operations Management Research, 1(2), pp. 103-118.

Oliva, R., \& Kallenberg, R. 2003. "Managing the transition from products to services". International Journal of Service Industry Management, 14(2), pp. 160-172.

Phumbua, S. 2012. "Simulation modelling of service contracts within the context of Product-Service Systems (PSS)”. Cranfield University Doctoral Thesis.

Phumbua, S., \& Tjahjono, B. (2010). Simulation Modelling of Product-Service Systems: the Missing Link. In S. Hinduja \& L. Li (Eds.) (pp. 135-138). Springer London. Retrieved from http://link.springer.com/chapter/10.1007/978-1-84996-432-6_31

Phumbua, S., \& Tjahjono, B. 2012. "Towards product-service systems modelling: a quest for dynamic behaviour and model parameters”. International Journal of Production Research, 50(2), pp. 425-442.

Reed, S., Andrews, J. and Dunnett, S., 2013. "Simulation driven design of functional products: a tool for evaluation of hardware reliability and maintenance”. International Journal of Product Development, 18(1), pp. 48-67.

Tukker, A., \& Tischner, U. 2006. New business for old Europe: product-service development, competitiveness and sustainability. Greenleaf Pub.

Weidmann, D., Maisenbacher, S., Kasperek, D., \& Maurer, M. S. 2015. "Product-Service System development with Discrete Event Simulation modeling dynamic behavior in Product-Service Systems”. In 9th Annual IEEE International Systems Conference, IEEE SysCon15, Vol. 14, pp. 133-138.

Wrasse, K., Hayka, H. and Stark, R., 2015. „Simulation of Product-Service-Systems Piloting with AgentBased Models (Outlined Revision)”. Procedia CIRP, 30, pp.108-113.

Zeithaml, V., Bitner, M.J. 2000. Service Marketing: Integrating Customer Focus Across the Firm (2nd ed.) Irwin McGraw-Hill Publishing Company, New York, NY 